\title{
ANADOLU AJANSI SORUNU VE ÇÖZÚM YOLLARI
}

Doc. Dr. Hikmet Sami TƯRK *

\section{GIRIS}

Anadolu Ajansı Türk Anonim Sirketi, bir süreden beri kamuoyunun dikkatini çeken konular arasında yer almaktadır. Ózellikle Mart 1978 sonundaki olayl Genel Kurul toplantısı ve onu izleyen gelişmeler, Anadolu Ajansı T.A.Ş. üzerindeki tartışmaların kolay kesilmeyeceğini göstermektedir. Şimdiye değin bu tartışmaların belirli bir yöneticinin görevinden uzaklaştırılması veya görevinde bırakılması noktasında yoğunlaşması, konunun objektif bir biçimde ele alınmasına olanak vermemiștir. Oysa Anadolu Ajansı sorununun herhangi bir yöneticinin kişilik ve tutumundan bağımsız yönleri de vardır. Incelememizde bu yönleriyle Anadolu Ajansı sorununun ne olduğunu ve nasıl çözülebileceğini araştırmaya çalı\$acă̆ız.

Konuyu başından alalım :

\section{ANADOLU AJANSI SORUNUNUN ORTAYA ÇIKIŞI}

\section{A - Anadolu Ajansı'nun Kuruluşu}

Anadolu Ajansı, Kuvayi Milliye hareketini yurda ve dïnyaya duyurmak amacıyla 6 Nisan $1920^{\prime}$ de, yani Türkiye Büyük Millet Meclisi'nin açılıs hazırlıklarının yapıldığı bir sırada Ankara'da kurulmuştur. Ulusal Kuntuluş Savaşımızın büyük önderi Mustafa Kemal'in bu konuda Anadolu ve Rumeli Müdafaa-i Hukuk Cemiyeti Heyet-i Temsiliyesi adına yayımladığı bildiride, Anadolu Ajansi'mın rbừtün Rumeli ve Anadolu'nun giriştiği ulusal ve kutsal sa-

\footnotetext{
* Ankara Universitesi Hukuk Fakültesi Ogretim Uyesi.
} 
vaş sırasında halkın en doğru iç ve dış haberlerle aydınlatılması zorunluğu önemle dikkate alınarak" kurulduğu belirtilmiștir.

IIk çalışmalarında Heyet-i Temsiliye'nin olanaklarından yararlanan Anadolu Ajansı, yeni Devletin örgütlenmeğe başlamasiyla merkezî idare yapısı içine alınmıştır. Gerçekten Anadolu Ajansı, Kurtuluş Savaşı boyunca, hätta Savaș ertesinde çalışmalarunı önce 7 Haziran 1920 tarih ve 6 sayll Matbuat ve tstihbarat Müidiriyet-i Umumiyesi Teskiline Dair Kanun'la İcra Vekilleri Heyeti (Bakanlar Kurulu) Başkanlığına, diğer bir deyişle Türkiye Büyük Millet Meclisi Başkanlığına bağlı bir öngüt olarak kurulan, sonra da 25 Aralık 1920 tarih ve 79 saylı Matbuat Müdiriyet-i Umumiye. sinin Hariciye Vekâletine Rabtına Dair Kanun'la Dışişleri Bakanliğı'na bağlanan Matbuat ve Istihbarat Müdiriyet-i Umumiyesi (Ba. sın ve İstihbarat Genel Müidürlügüi) içinde bir şube olarak sürdürmüştür².

Lozan Barış Antlaşmasi'nın imzalanmasından ve Cumhuriyet'in ilânından sonra Anadolu Ajansı, normal zamanların koşullarına ve yaptı̆̆ı ișlerin özelliklerine uygun bir hareket serbestliğgine, kısacası belirli bir özerkliğe kavușiturulmak istenmis ve 1341 Senesi Muvazene-i Umưmiye Kanunu (1925 Yulı Bütçe Kanunu) ile Ajans'ın bir özel kurum tarafından «idare ettirilmesine» Dışişleri Bakanı yetkili kulınmıștır (m. 33). Böylece Anadolu Ajansı, Devletin idari yapısı dışına çıkarılmış ve 1 Mart $1925^{\prime}$ de bir anonim ortaklık durumuna getirilmiștir.

\section{B - Anadolu Ajansı T.A.Ș. Anasözleșmesinin Temel Hüküim- leri}

«Anadolu Ajansı Türk Anonim Şirketi» unvanını taşıyan bu ortaklik, -Anasözleşmesine göre- dünyanin her yanından telgraf. telefon ve diğer araçlarla elde edeceği sìyasal, askerî, malî, ticarî, iktisadî, sınâ̂, tarımsal ve genel olarak uluslararası nitelikte büiün oiaylara ilișkin haberleri Türkiye ve diğger ülkelerde yine çeşitli

I Buraya sadeleştirilmiş biçimiyle yalnız bir bölümünü aldı̆̆ımız söz konusu bildirinin tam metni ve Anadolu Ajansı'nın kuruluşu hakkıında genis bilgi için bk. Aslan Tufan Yazman, «Anadolu Ajansı", tktisat ve Ticaret Ansiklopedisi, C. I, Istanibul 1946, s. 259 vd.

2 Bu konuda bk. Anadolu Ajansı Türk Anonim Sirketi, Sermayesi 20.000 Türk Lirası, Merkez-i Idaresi : Ankara, Mümessillikleri : Istanbul, Izmir, Adana, Haricî Muhabirlikleri : Cenevre, Bükres-Meclis-i Idare Raporu ve Murakıp Raporu, 1925 ve 1926 Seneleri Bilançoları ve Kâr ve Zarar Hesabi, Ankara 1927, s. 5. 
araçläla yaymak, bu amaçla biilten, servis ve korrespondanslar yayımlamak, ilâncılık yapmak, basımcı ve yayımcı olmak gibi işleri görmek üzere kurulmuştur. Kurucuları arasında Kars Milletvekili Ağaoğlu Ahmet, Mardin Milletvekili Yakup Kadri (Karaosmanoğlu), Karahisar Milletvekili Ruşen Essref (Unaydin), Bolu Milletvekili Falih Rtfkt (Atay) ve Ajans Başyazam Kemaleddin Kàmi (Kamu) gibi ünlüler de yer almaktadır (m. 1).

Başlangıçta 25 yıl için kurulan Anadolu Ajansı T.A.Ş.'nin süiresi, önce 1975, sonra da 1980 takvim yilı sonuna kadar olmak üzere iki kez uzatılmıștır (m. 4).

Anadolu Ajansı T.A.Ş.'nin temel sermayesi, her biri 10 lira değerinde 2.000 paya bölünmüiş 20.000 liradan ibarettìr. Ada yazılı olarak ve yalnız Türk hamilleri için düzenlenen pay senetlerinin yarısı, kuruluş sırașında Ajans'ta çalıșan memurlara dağıtılmıștır (m. 5).

Anadolu Ajansı T.A.Ş., Genel Kurulca -1973'de yapılan bir Anasözleşmie değişikliğinden sonra- iki yl için atanan ve üçten beşe kadar üyeden oluşan bir Yönetim Kurulunca yönetilir (m. 7). Lyelerden her birinin Ontaklığın 50 pay senedine sahip olması ve bunları görev süresi boyzunca satılamamak kaydıyla Ortaklık Sandığına tevdi etmesi gerekir (m. 11).

Genel Kurul ise, asil veya vekil słfatryla en az 10 paya malik pay sahiplerinden olușur. Her 10 pay bir oy hakkı verir. Ancak hiọbir pay sahibinin 10'dan çok oyu olamaz (m. 20). Hemen söy. leyelim ki, en çok oy hakkının 10 rakamı ile sınırlanmasına ilişkin Anasözleşme hüikmüi, aslında herhangi bir kişi veya grubun tek başına Anadolu Ajansı T.A.Ş.'ne egemen olmasını önlemeyi amaçlâdığı halde; -aşağıda göreceğimiz gibi- zamanla ters yönde işlemiş ve günümüzde Anadolu Ajansı sorununun temel nedeni olmuştur.

\section{C - Anadolu Ajansı T.A.S.'nde Payların Dağılımı ve «Devlet Iștiraki"}

Bașlangıçta Anadolu Ajansı T.A.Ș.'nin bütün pay senetleri gerçek kişilere ait olmakla birlikte, daha sonra yapılan devirler sonucunda Hazine (Maliye Bakanlığı) en büyükk pay sahibi durumuna gelmiștir. Gerçekten Mart 1978'de yllik olağan Genel Kurul toplantısına doğru Maliye Bakanlı̆̆ınca bazı kamu iktisadî teşebbüslerine yapılan devirlerden önce Anadolu Ajansı T.A.Ș.'nin 2.000 pay senedinden 955'i —ki bunların 850'si 1931'de Dışişleri Bakanı 
Tevfik Rüşiii (Aras) tarafından devredilmişti-, yani \% 47.75'i Hazine'ye, geri kalan $1045^{\prime} \mathrm{i}$, yani $\% 52.25$ 'i gerçek kişilere ait bulunuyordu. (Incelememizde son pay senedi devirlerinden önceki durum göz önünde bulundurulmuștur). Demek ki Anadolu Ajansı T.A.Ș.'nde - Hazine temel sermayenin yarısından azına sahip olduğu için- 12 Mart 1964 tarih ve 440 saylh tktisadî Devlet Teșekkülleriyle Müesseseleri ve Iștirakler Hakkında Kanun anlamında bir "Devlet iştiraki» söz konusudur (m. 1/II). Bunun en önemli sonucu, Devlet payının \% 15'i aștığı bir ortaklık olarak Anadolu AjanS1 T.A.Ș. Yönetim Kurulunda Maliye Bakanlığı'nca atanacak bir temsilcinin bulundurulabilmesi olmak gerekirse de; $\mathbf{4 4 0}$ saylı Kanun'un yürürlüğe girdiği tarihte mevcut ortaklukların kanun ve anasözleşmelerindeki hükümlerin saklı tutulması (m. 26/I), Anadolu Ajansı T.A.Ș. için bu olanaktan yararlanmayı engelleyici nitelikte gözükmektedir.

Öte yandan gerçek kişilerin elinde bulunan pay senetlerinden çoğunun sahipleri veya mirasçıları ile Anadolu Ajansı T.A.Ș. arasındaki iliş̧kiler yıllardan beri kesilmiş durumdadır. Bunlar, zaten kâr dağıtan bir ortaklık görünümü taşımayan Anadolu Ajansı T.A.Ş.'nde ișlerin gidiși ile ilgilenmemekte; Genel Kurul toplantılarına sadece Maliye Bakanlığı ile yönetimi elinde tutmaya kararlı bir küçük grup katılmaktadır. Nitekim son oniki yılda, yani Anadolu Ajansı T.A.S.'nin bir kayyım kurulunca yönetildiği 1965 isyllından sonraki dönemde yaplan olağan Genel Kurul toplantılarında Hazine payları dışında temsil edilen payların saylları ${ }^{3}$, - toplam pay sayısina, dolayısiyla temel sermayeye oranlarnyla birlikte- s1rayla şöyledir: 1966 'da 325 (\% 16.25), 1967'de 175 (\% 8.75), 1968 1969,1970 ve $1971^{\prime}$ de 150 (\% 7.5), 1972 ve 1973'de 75 (yalnız Yakup Kadri Karaosmanoğlu, \% 3.75), 1974'de 235 (\% 11.75), 1975 ve 1976'da 225 ( \% 11.25), 1977'de 200 (\% 10). Görüldügüi gibi Hazine dışındaki pay sahipleri, son oniki yllda yapılan olağan Genel Kurul toplantılarına en çok $\longrightarrow$ da yalnız bir kez- 325 pay, yani toplam payların \% 16.25'i ile katılmıslardır.

\section{D - Azınlık Yönetimi}

Fakat Anadolu Ajansı T.A.Ş. Anasözleșmesinde her 10 pay hir oy hakkı vermekle birlikte, hiçbir ay sahibinin 10 'dan çok oyu olamayacağının öngörülmesi (m. 20), Maliye Bakanlı̆̆ı'nın Hazi-

${ }^{3}$ Söz konusu pay saylan, Anadolu Ajansı T.A.Ş. Genel Kurul toplantılarında hazır bulunanları gösteren cetvellerden çıarılmıștır. Bu cetveller için bk. Ankara Ticaret Sicili Memurlưgu Dosya No. 416 (46). 
ne'ye ait 955 pay için Genel Kurulda ancak 10 oy kullanabilmesi sonucunu doğurmaktadır. Buna karşılık Genel Kurulda temsil ediIen diğer payların, sahipleri arasında en çok oy hakkı sınırlama. sından hiç, bir oy hakkı için gerekli en az pay sayısı koşulundan ise fazla etkilenmeyecek bir biçimde dağılmış bulunması ve onların da yıllardan beri genellikle belirli bir siyasal görüş̧ doğrultusunda oy kullanan bir grup meydana getirmesi, Anadolu Ajansı T.A.Ş, 'nde güç dengesini tersine çevirmiştir. Durumu daha iyi açıklayabilmek için, 1965 işyılını izleyen olağan Genel Kurul toplantılarında Hazine dışındaki pay sahiplerinin ellerinde bulunan pay sa* yılarin bir de hakları olan oy saylariyla birlikte siralayalım4: $1966^{\prime}$ da 325 pay -30 oy, $1967^{\prime}$ de 175 pay - 16 oy, 1968, 1969, 1970 ve 1971 'de 150 pay -14 oy, 1972 ve 1973 'de 75 pay -7 oy, 1974 'de 235 pay - 22 oy, 1975 ve 1976 'de 225 pay -21 oy, 1977 'de 200 pay - 19 oy.

Böylece son oniki yılda yapilan olağan Genel Kurul toplantılarunda toplam payların en çok \% 16.25'ini temsil eden bir gxup, en çok oy hakkı sınırlamasından ileri gelen bir oy üstünlüğü ile Anadolu Ajansı T.A.Ş. yönetimine tek başına egemen olabilmiş; toplam payların \% 47.75'ine sahip Hazine ise azmllk durumuna düşmüsstür. Üstelik Anadolu Ajansı T.A.Ș.'nin her yll Devlet bütçesinden milyonlarca liralık ödenek alması, çelişkiyi ağırlaștırmaktadır. Anadolu Ajansı T.A.S. yöneticilerinden farklı siyasal görüșteki kadrolann iktidarda bulunduklan dönemlerde ise - son olaylarda da görüldüğỉ gibi- çelişkinin boyutları genişlemektedir.

Bu nedenlerle Anadolu Ajansı T.A.Ș.'nde azınlığı çoğunluk, çoğunluğu azınlık yapan şimdiki çarpık sistemin düzeltilmesi veya değiștirilmesi yararlı olacaktır. Ancak bu yapılırken Anayasamızın şu hïkmü göz önünde tutulmalıdır:

"Devlet tarafından kurulan veya Devletten malî yardım alan haber ajanslarının tarafsızlığı esastır» ( $\mathrm{m}$. 121/IV).

\section{III. ÇÖZÙM YOLLARI}

Anadolu Ajansı sorunu için düșüinülebilecek çözüm yollam iki ayrmoda ele almabilir:

${ }^{4}$ Oy saylları, yuk. dn. 3'te sözü edilen cetvellerde yazıl pay sayılarn üze rinden Anadolu Ajansı T.A.S. Anasözleşmesinin 20. maddesı hükümlerine gore hesaplanmıștır. 
A - Anadolu Ajansı'nın durumunu anonim ortaklık statüsü içinde düzeltmek. İlk ayrımdaki çözüm yolları, Anadolu Ajansı'nın nukukî varlığını anonim ontaklık olarak sürdürmekle birlikte, şimdiki çarpık sisteme son verebilecek tedbirlerin araştırılmasına yöneliktir. Burada çeșitli seçenekler söz konusu olabilir:

1. Anadolu Ajansı T.A.Ş. Anasözleşmesinin azınlık yönetimine yơ açan hükümlerini değiştirmek;

2. Bu hükümlerin korunmasına olanak veren 1 Temmuz 1960 tarih ve 7 sayıl Anadolu Ajansı Türk Anonim Şirketinin 6762 Sayılı Türk Ticaret Kanununun 272. Maddesinden Istisna Edilmesine Dair Kanun'u kaldırmak veya değiştirmek;

3. Hazine'ye ait pay senetlerinden bir bölümünü Anadolu Ajansı T.A.Ş.'nin çalıșma konusu ile ilgili kamu iktisadî teşebbüslerine devrederek Genel Kurulda denge sağlamak;

4. 2 Temmuz 1963 tarih ve 265 sayll Turizm ve Tanitma Bakanlığı Kanunu'nun 33. maddesinden yararlanarak Anadolu Ajansı T.A.Ș. yöneticilerinin atanmasunda etkili olmak.

B - Anadolu Ajansı'nı özerk/tarafisız bir kamu tüzelkişiliği olarak yeniden örgütlemek. Ikinci ayrımdaki tek çözüm yolu, Anadolu Ajansínın anonim ortakklık olarak hukukî varlığına son verilmesine ve özerk/tarafsız bir kamu tüzelkișiliği olarak yeniden kurulmasına yöneliktir.

Şimdi bu çözüim yollarını inceleyelim :

\section{A - Anadolu Ajansi'nun Durumunu Anonim Ortakhk Statüsüi İçinde Diizeltmek}

Yukarda Anadolu Ajansı'nın durumunu anonim ortaklık statüsü içinde düzeltmeğe yönelik çözüm yolları olarak sıraladığımız dört seçenekten ilk ikisi, doğrudan doğruya veya dolayısıyla Anadolu Ajansı T.A.Ş. Anasözleşmesinde değișiklik yapılması ı́le ilgilidir. Birinci seçenekte bu değișikliğin yürürlükteki mevzuat çerçevesinde gerçekleştirilmesi, ikincisinde ise bu değişikliğin yapılmasını sağlamak üzere önce 1 Temmuz 1960 tarih ve 7 sayll Kanun'un kal. dıralması veya değiştirilmesi söz konusudur. Son iki seçenege gelince; bunlar, Anadolu Ajansı T.A.Ş. Anasözleşmesinde herhangi b:r değişiklik olmadan da uygulanabilecek tedbirlerle ilgilidir.

Sırayla bu seçenekleri biraz daha yakından görelim: 
i. Anadolu Ajansı T.A.S. Anasözleșmesinde Değisiklik Yapmak

a) Türk Ticaret Hukukunun Tar i h I Ge. lişmesi 1 çinde Anadolu Ajansı T.A.\$. An asözleşmesi ve Oy Hakkini Kisit. l a y $1 \mathrm{cl}$ H $\ddot{\mathbf{u}} \mathbf{k} \ddot{\mathbf{u}} \mathbf{m} l$ e r $\mathbf{i}$

Anadolu Ajansı T.A.Ș. Anasözleșmesi, 18 Ramazan 1266 (28 Temmuz 1850) tarihli Kanunnamè-i Ticaret'in anonim ortakliklar alanındaki düzenleme yetersizliğini gidermeğe yönelik bir örnek anasözleşme olarak 17 Mulharrem 1300/17 Teşrinisani 1298 (29 Kasım 1882) tarihli bir «irade-i seniye» (padişah emri) ile yayımlan. mış bulunan Anonim Şirket Nizamname-i Dahilîsi'ne göre hazırlanmıştır ${ }^{5}$. Anadolu Ajansı T.A.S. Anasözleșmesinin Genel Kurulun asil veva vekil sifatiyla en az 10 paya malik pay sahiplerinden olușacağı, her 10 payın bir oy hakkı vereceği, ancak hịbir pay sahibinin 10'dan çok oyu olamayacağına iliş̧in 20. maddesi, adı geçen örnek anasözleşmenin 25 . maddesindeki bos yerlere $\longrightarrow$ dönemdeki yaygin uygulamaya paralel olarak - 10 rakammin konması suretiyle yazılmıștır.

Daha sonra yuirürlïge giren 29 Mayıs 1926 tarih ve 865 sayll Ticaret Kanunu da, anonim ontaklikların anasözlesmelerinde bu çeşit kaytlarm yer almasına olanak tantyor, hatta hiçbir pay sahibirinin 10 'dan çok oyu olamayacağı ilkesini açıkca benimsiyordu (m. 365/I). Fakat Ticaret Kanunu'na göre bu çeşit kayıt ve kısıtlamalar anasözleșme deģișiklikleri ile ilgili toplantılar bakımından geçerlik taşımayacaktı (m. 385/III). Böylece Kanunname-i Ticaret döneminde hazırlanmış bulunan Anadolu Ajansı T.A.Ș. Anasözleş. mesinin birçok maddesi gibi 20. maddesi de Ticaret Kanunu döneminde herhangi bir değişikliğe uğramaksızın kalabilmiștir.

Buna karşılık 29 Haziran 1956 tarih ve 6762 saylı Türk Ticaret Kanunu, 865 sayll eski Ticaret Kanunu'nun sistemini terk ederek, her pay senedinin en az bir oy hakikı vereceği hükmünü koymuş (m. 373/I); anasözleşme değişikliği için yapılan toplantıda ise, anasözleșmede tersine hüküm bulunsa bile, her pay senedinin ancak bir oy hakkı vereceğini belirtmiștir (m. 387). Türk Ticaret Ka. nunu Tasarısına ilișkin Adalet Komisyonu Tutanağında "her hisse

\footnotetext{
${ }^{5}$ Anonim Şirket Nizamname-i Dahilîsi metni için bł. Diistur, 1. Tertip, Zeyl 3, s. 160-168; Dersaadet Ticaret Odasi Gazetesi, 23 \$aban 1326/6 Ey. liil 1324, No. 1237, s. 302 vd + 30 Saban 1326/13 Eyliul 1324, No. 1238, s. 310-312. Anadolu Ajansı T:A.Ş. Anasözleşmesinin ilk metni için bk. Anadolu Ajansı Türk Anonim Şirketi Nizamname-i Dahilîsi, Istanbul 1925-1341.
} 
senedinin en az bir rey hakkı vermesi esası da âmir hüküm olarak kabul" edildiği yazılıdır'.

Türk Ticaret Kanununun Mer'iyet ve Tatbik Şekli Hakkmdaki 6763 sayılı Kanun (veya yaygin kısa adıyla Tatbikat Kanunu), "Anonim şirket» ile ilgili geçiş hükümleri arasında önce "Umumî olarak» kenar başlıkh 19. maddesiyle, Türk Tícaret Kanunu'nun yürürlïğe girdiği tarihte ticaret siciline kayıtlı anonim ortakltklar hakkında yeni Kanun'un 317-346, 360-363, 370, 374, 385, 386 ve 398. maddeleri ile anasözleșmelerinin hükümlerine aykırı olmayan di. ğer hükümlerinin uygulanacağını öngörmüuş; sonra da «Esas mukavelenin yeni kaidelere uydurulması» kenar başlıkl1 20. maddesiyle, aynı anonim ortaklıklardan anasözleşmeleri yeni Kanun'un anılan maddeleri dıșındaki "âmir hükümlerine" uymayanlarnn iki yıl içinde anasözleşmelerini yeni hükümlere uydurarak tescil ettirmedik. leri takdirde "münfesih» saylacaklarını belirtmiștir (f. I). Bu süre, daha sonra sirayla 15 Aralık 1958 tarih ve 7178 sayll, 21 Aralık 1959 tarih ve 7400 sayll, son olarak da 21 Kasım 1960 tarih ve 135 sayılı Kanun'la üç kez uzatılııştır. Sonuncu Kanun'la verilen süre 1 Nisan 1961 tarihinde dolmuștur.

\section{b) $7 \mathrm{~S}$ a y $1 \mathrm{ll} \mathrm{K}$ a nu}

Genel nitelikteki bu kanunlara göre Anadolu Ajansı T.A.Ș.'nin de Anasözleşmesinin 20. maddesini Türk Ticaret Kanunu'nun -6763 saylı Tatbikat Kanunu'nun 19. maddesinde dogrudan doğ. ruya uygulanacağı öngörülmemiş - 373. maddesinin her pay senedinin en az bir oy hakkı vereceğine ilişkin emredici hükmüne uygun bir duruma getirmesi gerekirdi. Ne var ki, Anadolu Ajansı T.A.Ş. için 1 Temmuz 1960 tarihinde 7 sayı ile özel bir kanun çıkarılmıştır. Millî Birlik Komitesi döneminde çıkarılan diğer kanunlar gibi bu kanun için de herhangi bir gerekçe yayımlanmamıştır. Söz konusu kanun «Anadolu Ajans1 Türk Anonim Şirketinin 6762 Sayil Türk Ticaret Kanununun 272. Maddesinden Istisna Edilme. sine Dair Kanun» baş̧ı̆̆ını taşımaktadır. Başlıkta anılan Türk Ti. caret Kanunu'nun 272. maddesi, özel kanunlanda tersine hüküm bulunmadıkça anonim ortaklıklarda temel sermaye miktarının 500.000 Türk lirasından aşağı olamayacağına iliş̧kindir. 7 saylı Ka. nun'un başlığg okununca kanun koyucunun Anadolu Ajansı T.A.Ș.'ni bu en az sermaye koşulundan "istisna" etmek istediği anlaşıllır.

- Bk. Hatid Kemal Elbir, Gerekçeli-Notlut-Sistematik Türk Ticaret Kanunu ve Tatbikat Kanunu ile AJâkaIı Mevzuat, 2. bası, tstanbul 1958, s. 147 vd. m. 373 , s. 149 m. 387. 
(Hatırlanacağı üzere Anadolu Ajansı T.A.Ş.'nin temel sermayesi 20.000 liradır). Fakat hukukî bakımdan birinci derecede önem taşıyan kanun metni biraz değişiktir. Gerçekten 7 sayılı Kanun'da -yürürlük tarihi ve yürüten makamla ilgili klasik maddeler dışın. da- 1. madde olarak șu tek hüküm yer almaktadır :

«Anadolu Ajansı Türk Anonim Şirketi, 6762 sayılı Tüirk Ticaret Kanununun anonim șirketlere ait intibak hükümleriyle 272. madesi hükmünden istisna edilmiștir».

Bu hükü̈mde - Kanun başlığında bulunmayan bir ibarenin eklenmesinden ötürüi-farklı yorumlara elverişli bazı anlatım yanlışları veya kusurları vardır. \$̧öyle $\mathrm{ki}$ :

$1^{\circ} 6762$ sayılı Türk Tícaret Kanunu'nda anonim artaklıklara ilişkin herhangi bir «intiöok» hükmü yoktır. Bu çeşit hükümler, Türk Ticaret Kanununun Mer'iyet ve Tatbik Sekli Hakkındaki 6763 sayll Kanun'un özellikle «Esas m'skavelenin yeni kaidelere uydurulması" kenar başlıkl 20. maddesinde bulunmaktadır. Imdi 7 sayılı Kanun'un yalnız doğru anlatımlı sözüne ağılık veren bir yorumla, kanun koyucunun Anadolu Ajansı T.A.Ş.'ni 6763 sayılı Tatbikat Kanunu'nun 20. maddesi hükmünden degil, sadece 6762 sayll Türk Ticaret Kanunu'nun en az sermayeye ilişkin 272. maddesinden «istisna» etmek istediği öne sürülebilir. Hatta böyle bir yorumu desteklemek ỉzere șu noktalar da eklenebilir :

- Eğer 7 saylı Kanun'la 6763 sayll Tatbikat Kanunu'nun 20. maddesi kastedilmiş olsaydı, o zaman 6762 saylh Türk Ticaret Kanunu'nun 272. maddesinin ayrica belintilmesine gerek kalmazdi. Çünkü 6763 sayll. Tatbikat Kanunu'nun 20. maddesinde açkça öngörtilen «Esas mukavelenin yeni kaidelere uydurulması" işlemlerinden birisi de, temel sermayelerin 500.000 liraya çkarilmasıdır (f. III).

- 7 sayll Kanun'un en az sermaye koșulu dışında da Anadolu Ajansı T.A.Ş. Anasözleșmesini geçerli saydığını kabul edebilmek için, yukarda anulan 1. maddesinin «Anadolu Ajansı Türk Anonim Sirketi, Türk Ticaret Kanununun Mer'iyet ve Tatbik Sekli Hakkındaki 6763 sayll Kanunun anonim şirketlere ait intibak hükümlerinden istisna edilmiştir.s biçiminde olması gerekir ve yeterdi. Nitekim 6763 sayll Tatbikat Kanunu'nun 20. maddesindeki iki y1llik sïreyi uzatan 7178,7400 ve 135 sayılı kanunların gerek başlikların$\mathrm{da}$, gerek metinlerinde hep «Tïk Ticaret Kanunun Mer'iyet ve Tatbik Șckli Hakkındaki 6763 saylı Kanunwdan söz edilmiștir. 
Bu saptamalar, 7 sayılı Kanun'un aslinda Anadolu Ajansı T.A.Ș.'ni — doğru amılan kanun sayısı, adı ve madde numarasıylaTürk Ticaret Kanunu'nun yalnız en az sermaye koşuluna ilișkin 272. maddesinden «istisna» etmeyi amaçladığını, geri kalan Anasözleşme hükümlerinin Türk Ticaret Kanunu'nun emredici hükümlerine uydurulması gerektiğini düşïndürecek niteliktedir. Bu yapılmadığı takdirde 6763 sayıll Tatbikat Kanunu'nun 20. maddesi gereğince Anadolu Ajansı T.A.Ș., en son 135 sayılı Kanun'la verilen uzatma süresinin bittiği 1 Nisan 1961 tarihi itibariyle «münfesih» sayllabilir. Fakat daha sonra çıarlan 2 Temmuz 1963 tarih ve 265 sayll Turizm ve Tanitma Bakanliğı Kanunu'nun -ilerde ayrıca inceleyeceğimiz- «Anadolu Ajansı Hle sözleșme» kenar bașlıklı 33. maddesi ve bu madde uyarnca her yll Bütçe Kanununa Anadolu Ajansı için ödenek konması dikkate alınırsa, kanun koyucunun bu kuru!ışu böyle bir yaptırımın dışında görduigüi, başka bir deyişle onun hukukî varlığını bir veri olarak kabul ettiği anlașıılır. Öyleyse 7 sayılı Kanun'un elverișli olduğu ilk yorumda -diğer kanunları da göz önünde bulundurmak kaydryla- varlabilecek sonuç özetle şudur: Anadolu Ajansı T.A.Ș.'nin Anasözleșmesini Türk Ticaret Kanunu'nun 272. maddesindeki en az sermaye koşulu dıșındaki emredici hükümlerine uygun duruma getirme konusunda ancak yaptlrımsız bir yükümü olduğundan söz edilebilir.

$2^{\circ} \quad$ Ilk yorumun eksik yan, 7 saylı Kanun'un 1 . maddesine her nasılsa sıkış̦tırılmıș bulunan «... anonim şirketlere ait intibak hükü̈mleriyle...» ibaresini açılamamasıdır. 7 sayılı Kanun'da -meski bir deyișle- bir "zaaf-ı telif», yani bir anlatım bozukluğu olsa bile, söz konusu ibareyi "haşiv", yani gereksiz söz saymak olanaksızdır. Iște bu düșünceden hareket ederek 7 sayılı Kanun'un yalnız doğru anlatıml sözüne değil, tïmüne eşit ağırlık veren ikinci bir yorum. da «... anonim şirketlere ait intibak hükümleriyle...» ibaresini de anlamlandırma zorunluğu olduğu, dolayısıyla bu ibarevi «... Türk Ticaret Kanununun Mer'iyet ve Tatbik Sekli Hakkındaki 6763 sayılı Kanunun anonim şirketlere ait intibak hükümleriyle.... biçiminde anlamak gerektiği sonucuna varılabilir. Bu durumda 7 sayılı Kanun'un 1. maddesinde Anadolu Ajansı T.A.S.'nin "6762 sayl11 Türk Ticaret Kanununun... 272. maddesi hükmünden istisna» edildiğinin ayrıca belirtilmesi, en az sermaye koșuluna özel bir önem verilmesinden ileri gelmiş olabilir. Açuktır ki, böyle bir yorumda Anadolu Ajansı T.A.Ș.'nin Anasözleşmesini Türk Ticaret Kanunu'nun emredici hükümlerine uygun duruma getirme konusunda herhangi bir yükü̈mü olduğundan söz edilemez. 
c) A nadolu A jans 1 T.A.S. An a sözle s mesinin Defistirilmesi

Fakat bu, Anadolu Ajansı T.A.Ş. Anasözleşmesinin değiștirilemeyeceği anlamına gelmez. Nitekim 7 sayıl Kanun döneminde Anadolu Ajans1 T.A.Ş. Anasözleșmesinde Yönetim Kurulunun iki yılda bir seçilmesi (m. 7), Ontakltk süresinin 1980 takvim yllı sonuna kadar uzatılması (m. 4) gibi ufak bazı değişiklikler yapılmıştır ${ }^{7}$. Aymı biçimde Anadolu Ajansı T.A.Ş., Genel Kurulda oy hakkını kısıtlayıcı hüikümlerin kaldırılmasını da içeren bir Anasözleşme değişikliğini her zaman gerçekleştirebilir; hatta temel sermayesini 20.000 liradan 500.000 liraya çıkarabilit. Kesin olan şey, bu değişikliklerin 7 sayılı Kanun'a aykırn düişmeyeceğidir. Çünkü 7 sayılı Kanun'un amaci, belli bir hukukî durumu dondurmak değil, onun korunmasına olanak vermektir. Bu olanaktan her zaman vazgeçilebilir.

İlginçtir ki, 7 sayılı Kanun'un çıarıldığı 1960 yılı ile onu izleyen ilk yıllarda görev yapan Anadolu Ajansı T.A.Ş. yönetim kurullarinın sirasiyla 15 Mart 1961, 23 Mart 1962 ve 15 Mart 1963 günleri toplanan olağan genel kurullara sundukları çalışma raporlarında ${ }^{8}$, Anadolu Ajansı T.A.Ş.'nin geleceği ile ilgili işler arasında gerek Türk Ticaret Kanunu'nun 272. maddesinde yazılı en az sermaye koşulunu yerine getirmek iizere sermaye artırmm yapılması, gerek Türk Ticaret Kanunu'nun diğer exnredici hükümlerine uyulması zorunluğuna işaret edilmiş; Devrim Hükümetinin «intibak» işlemlerini «muvakkaten» durdurduğu göriş̧üne yer verilmiştir. Bu raporlarda ayrıca yürürlükte bulunan Anadolu Ajansı T.A.Ş. Anasözleșmesinin günün gereksinmelerini karșılamaktan uzak olduğu, Anadolu Ajansı'nın «yarı resmî» niteliği olmakla birlikte çok partili dönemde çalışmalarını abjektif ölç̧ỉler içinde yü̈rütmesi gerektiği, nitekim 1961 Anayasasının 121. maddesinin Devletten malî yardım alan haber ajansları için tarafsızlık ilkesini koyduğu, dolayısıyla Anadolu Ajansı'nın hukukî̀ yapısının yeni baştan düzenlermmesinin ele alknacak ilk ișlerden olduğu belirtilmiștir.

Fakat aradan bunca yıl geştiği halde, Anadolu Ajansı T.A.Ş. Anasözleşmesini ne Türk Ticaret Kanunu'nun emredici hükümlerine, ne çă̆ın gereksinmelerine uygun duruma getirme konusunda herhangi bir girișimde bulunulmamıștır. Oysa en büyük pay sahibi

7 Bu değişiklikler için bk. Türkiye Ticaret Sicili Gazetesi, 18.3.1975, S. 93, s. 63 ve 25.3 .1975 , S. 98, s. 37.

8 Bu raporlar için bk. Ankara Ticaret Sicili Memurluğu Dosya No. 416 (46). 
sıfatıyla Maliye Bakanlığı, bütün bu noktaları dikkate alan bir Anasözlç̧me değişikliği önerisi hazırlayarak Anadolu Ajansı T.A.Ș. Genel Kurulunun olağanüstü toplantıya çağrilmasını isteyebilirdi. Anadolu Ajansı T.A.Ș. Anasözleșmesi, temel sermayenin üçte birine malik pay sahipler:ne Yönetim Kurulundan Genel Kurulu olağanüstü toplantıya çăğrmasını isteme yetkisi vermiștir. Yönetim Kurulu. nun bu isteği yerine getirmekten kaçınması durumunda Ticaret $\mathrm{Ba}$ kanlığı'nın Genel Kurulu olağanüstü toplantıya çağırması öngörülmüş̧ür (m. 19, krş. 24).

Ancak Anadolu Ajansı T.A.S. Anasözleșmesinin Genel Kurulda oy hakkını en çok 10 rakamı ile sımırlayan 20 . maddesi karșısında, -daha önce Maliye Bakanlığı ile diğer pay sahipleri arasinda bir uzlașmaya varlmadıkça- özellikle bu sınırlamanın kaldırılmasına yönelik bir değişiklik önerisinin geçirilmesinde güçlükle karşılaşılabilit. Gerçi Türk Ticaret Kanunu'nun 387. maddesi, anasözleşme değişikliği için yapılan toplantıda, anasözleşmede tersine hüküm bulunsa bile, her pay senedinin ancak bir oy hakkı vereceği kuralı. nı koymuştur. Fakat bu madde her nedense 6763 sayılı Tatbikat Kantinu’nun doğrıdan doğruya uygulanacağını öngördüğüi hükï̀mler arasinda anılmadığ için (m. 19, ayrıca 20/IV), Anadolu Ajansı T.A.Ș. Anasözleşmesinin değiş̧tirilmesi ile ilgili toplantıda da bu Anasözlesmenin oy hakkını kısıtlayıcı 20. maddesi geçerli kalacaktir.

d) Nasıl Bir Anasözleşme Değișikliği?

Öte yandan Anadolu Ajansı T.A.Ș. Anasözleşmesindeki oy hakkı smilamasının kaldırılması, Anadolu Ajansı T.A.Ș.nin tamamıly en büyïk pay sahibi Maliye Bakanlı̈̆1'nın kontrolï altna girmesi sonıcunu doğuracaktır. Buysa —dengeleyici başka tedbirler alın. mazsa- siyasal iktidarların Ajans yönetimine egemen olmalarını son derece kolaylaştıracaktır. Anayasamızın 121. maddesindeki tarafsızlık ilkesinin işlerliği açısından böyle bir durumun sakmcası crtadadır. Șüphesiz Anadolu Ajansı T.A.Ș.'ni azınlık yönetiminden kurtarmak isterken bu kez onu siyasal iktidarların kontrolü altına sokacak yeni bir yanlıştan kaçınmak gerekir. $O$ yüzden Anadolu Ajansı T.A.S.'nde azınlığı çoğunluk, çoğunluğu azınlık yapan şimdiki çarpık sisteme son verecek bir Anasözleșme değișikliğinin Yönetim Kurulunda en buiyük pay sahibi Maliye Bakanlığı'nın yanında azınlığın, hatta Ajans çalışanlarının temsiline olanak tanıyacak bir karma sisteme yönelmesi, Anayasamızın 121. maddesindeki taraf. sszlık ilkesine uygunluk bakımından yerinde olur. Ayrıca böyle bir 
karma sisteme gidilmesi, Anadolu Ajansı T.A.Ş. Anasözleşmesinde yapılacak değişiklikk konusunda Maliye Bakanlığı ile diğèr pay sahipleri arasında bir uzlașma temeli bulunmasma yardımce olabilir.

\section{7 Saytl Kanun'u Kaldirmak veya Değiștirmek}

Anadolu Ajansı T.A.Ş.'nde güç ıdengesini tersine çevirerek azınIlk yönetimine yol açan Anasözleşme hükkümlerinin değiștirilmesine olanak sağlayacak, hatta bunu zorunlu kılacak en güvenli yol, 7 sayılı Kamun'un tamamiyla kaldırnlması veya 1. maddesindeki «....anonim șirketlere ait intibak hükümleriyle...» ibaresinin çıkarılması ve böylece başlığı ile metni arasındaki uyumsuzluğun giderilmesidir. Fakat bu amaçla çıkarlacak kanunda Anadolu Ajansı T.A.Ş.'ne Anasözleşmesini Türk Ticaret Kanunu'nun «âmir hükümlerine» uy. clurabilmesi için 6 ay - 1 yl gibi bir sürenin verilmesi yerinde olur.

Ikinci aşamada yapılacak Anasözleșme değişikliği sonucunda Anadolu Ajansı T.A.Ş.'nin Maliye Bakanlığı eliyle siyasal iktidarla. rın kontrolï altına girmesi olasıltğına karșı dengeleyici tedbirlere yer verilmesi zorunluğuna burada da işaret etmek gerekir.

3. Hazine'ye Ait Pay Senetlerinden Bir Bölïmünü Kamu Iktisadî Teşebbüslerine Devretmek

Anadolu Ajansı T.A.Ş. Anasözleşmesinin Genel Kurulda hịbir pay sahibinin $10^{\prime}$ dan cok oyu olamayacağna ilişkin 20 . maddesi yüzünden azmlik yararına bozulan dengeyi yeniden kurmak üzere șimdiye değin ïzerinde en çok durulan ve Mart $1978^{\prime}$ de ylllık olagan Genel Kurul toplantısına doğru uygulamasına geçilen tedbir budur. Düșünülen, Hazine'ye ait pay senetlerinden bir bölüimünü Anadolu Ajansı T.A.Ş.'nin çalışma konusu ile ilgili bazı kamu iktisadî teşebbüslerine devrederek Hazine'nin elinde 10 rakamıla donmuş bulunan oyları yeniden canlandırmaktır. Gerçekten sadece üç kamu iktisadî teșebbüsüne 100 'er pay senedi devretmekle Hazine'nin 10 oyu yanmda 30 oy daha canlandırılmıs olacağı için, Anadolu Ajansı T.A.Ş.'nin 1965 işyllından sonraki olağan Genel Kurul topiantılarmda en çok toplam 325 pay ve 30 oyla temsil edilmiş bulunan azınlık karşısında denge kurulabilir.

Bilindiği gibi 440 sayll İktisadî Devlet Teşekkülleriyle Müiesseseleri ve Iştirakler Hakkında Kanun'a göre, "veraset ve sair yollarla "meydana gelmiş» Devlet iştiraklerinin «devir veya tasfiyesi» Ba. kanjar Kurulu kararıyla yapılmak gerekir (m. 4/III). Fakat büitçe kanunlarında her yll «Kamu ortaklarnnı ve iştiraklerinin yeniden düzenleme tedbirlerini gerçekleştirmek» amacıyla "Hazinenin ve 
kamu iktisadî teşebbüslerinin sermaye paylarını diǧer kamu iktisadi teşebbüslerine devrettirmeye ve onlar tarafindan da devraldırmaya" Maliye Bakanını yetkili kılan bir hükuim yer almaktadır (örneğin 1978 Yılı Bütçe Kanunu m. 67). Öyleyse Maliye Bakanlığı, bu yetkiden yararlanarak Hazine'ye ait Anadolu Ajansı T.A.Ş. pay senetlerinden bir bölümünü kamu iktisadî teşebbüslerinden kendi kanunlarında yazılı amaç ve çalışma konuları itibariyle hem Anadoiu Ajansı T.A.Ş.'nin çalıșma konusu ile ilgili sayılabilecek, hem bașka ortaklıklara katılabilecek olanlara devredebilir.

Fakat bu tedbir uygulanırken anonim ortaklıklar hukuku açıandan dikkat edilmesi gereken bazı noktalar vardır:

- Türk Ticaret Kanunu'na göre, oy hakkına ilișkin kısıtlamalardan birini etkisiz bırakmak amacryla pay senetlerinin genel kurulda oy hakkm kullanmak üzere ubaşkasına verilmesi caiz değildil'» (m. 361/I. Tatbikat Kanunu m. 19). O yüzden Hazine'ye ait Anadolu Ajansı T.A.S. pay senetlerinin bunlar üzerindeki mülkiyet hakkını, dolayısıyla bunlarla belgelenen pay sahipliği sıfatını tam olarak ilgili kamu iktisadî teşebbüslerine geçirmek üzere devredilmesi zorunludur'.

- Anadolu Ajansı T.A.Ș. Anasözleşmesine göre, "Șirketin his. se senedatının devir ve ferăğ Meclis-i Idare kararyyla icra olunur" (m. $15 \mathrm{sc}$ ). Bu hüküm, Anadolu Ajansı T.A.S. pay senetlerini anonim ortaklıklar hukukunda "bağlı ada yazılı pay senetleri» (Al. "vinkulierte Namensaktien», Fr, "actions nominatives liees») olarak nitelenen kategoriye solkmakta ve Yönetim Kuruluna pay senetleri devirini onaylamama, başka bir deyișle devrin Anadolu Ajansı T.A.Ș.'ne karşı hüküm ifade edebilmesi için gerekli olan pay defterine kayıt işlemini yapmaktan kaçımma olanağ1 vermektedir (Türk Ticaret Kanunu m. 416-418, Tatbikat Kanunu m. 19). Gerçi anonim ortaklıklar hukukunda ortaklik anasözleşmesiyle pay senetleri devrinin neden göstermeksizin pay defterine kaydından kaçınılabj!eceğinin öngörüldüğui durumlanda bile bu konudaki takdir yetkisj ksyfîlik anlamına gelmez ${ }^{10}$. Ama Anadolu Ajansı T,A.Ş. Yönetim

${ }^{9}$ Bk. Hatil Arslanlt, Anonim Sirketler, II-III, Istanbul 1960, s. 32-Fritz Funk, Kommentar des Obligationenrechtes, Bd. II, Aarau 1951, Art. 691 N. 1; E. Schucany, Kommentar zum Schweizerischen Aktienrecht, 2. Aufl., Zürich 1960, Art. 691 N. 1.

${ }^{10}$ Bk. Yaşar Karayalçtn, Özel Hukukda Meseleler ve Görüşler "Hukukî Mütalâalar», Ankara 1975, s. 248-256 "Bağlı Nama Yazılı Senetler-Tasdikten Kaçınma” (Yaşar Kanayalçın/Hikmet Sami Türk), özellikle s. $250 \mathrm{vd}, 254$. 
Kurulunun Maliye Bakanlı̆̆g'nca kamu iktisadî teşebbüislerine yaprlan pay senetleri devrini pay defterine geçirmekten kaçınması üzerine uyuşmazlığı mahkemeye götürmekten bașka hukukî çare voktur.

Öte yandan Hazine'ye ait pay senetlerinden bir bölümünü kamu iktisadî teşebbüislerine devretmek, Anadolu Ajansı T.A.S.'nin Maliye Bakanlığı araçlığıyla siyasal iktidarlarn kontrolü altına girmesi olasılığını ortadan kaldırmaz. Çünküi kamu iktisadî teşeb. büslerinin Maliye Bakanlı̆̆ı çevresinde aynt doğrultuda hareket eden bir grup meydana getirmesiyle de benzer bir sonuca ulaşılabilir. O yüzden bu seçenekte Anadolu Ajansı T.A.Ș. Genel Kurulu vanında Yönetim Kurulunun da dengeli bir yapıya kavuşturulması, tarafsızlık ilkesinin işlerliği açısından gereklj bir ek tedbir olarak düşünülmelidir.

4. Turizm ve Tantma Bakanltğ̆ Kanunu'nun 33. Maddesinden Yararlanmak

a) Anadolu Ajansi ile Devlet Arasındaki Hukukî lliskilerin Tarihî Gelismesi

2 Temmuz 1963 tarih ve 265 sayll Turizm ve Tantma Bakanlığı Kanunu'nun 33. maddesi, Bakanlığa Anadolu Ajansı ile ilgili önemli bazı yetkiler vermektedir. $\mathrm{Bu}$ yetkilerin niteligini daha iyi anlayabilmek için Anadolu Ajansı ile Devlet arasındaki hukukî ilişkłlerin tarihî gelişmesini ana çizgileriyle izlemekte yarar vardır:

Başlangıçta Matbuat ve İstihbarat Müdiriyet-i Umumiyesi'nin bir şubesi iken 1925 yılında idarî yapı dışına çıkarılarak bir anonim ortaklık durumuna getirildikten sonra Anadolu Ajansı - Devlet ilişkileri, belirli süreler için yapılan sözleşmeler çerçevesinde yürưituilegelmiștir. Bu sözleşmeler gereğince Devlet, Anadolu Ajans'nın habercilik hizmetlerinden yararlanmakta, karşıllı̆ında Anadolu Ajansı'na malî yardım yapmaktadır. Ancak bu sözleşmeler Devlet yönünden malî yükklenme anlamına geldiği ve 1924 Anayasasının 26. maddesine göre bu çeşit sözleşmelerin onanması ve bozulması aslında Türkiye Büyü̈k Millet Meclisi'nin görevleri arasinda olduğu için, yapılmalarına kanunla yetki verilmesi yoluna gidilmiştir.

Ilk olarak 1341 Senesi Muvazene-i Umumiye Kanunu (1925 Yılı Bütçe Kanunu), hem Anadolu Ajansı́nın bir özel kurum tarafundan «idare ettirilmesine», hem bunun için yıllık ödeme miktarı 150.000 liray1 geçmemek üzere on yıla kadar "taahhüt icrasına» 
Dişişleri Bakanını yetkill kılmıştır (m. 33). -Aynı dönemde çıarlan 17 Mayıs 1928 tarih ve 1265 sayılı Kanun'a" göre de Dıșișleri Bakanı, Anadolu Ajansı T.A.S. tarafından yurt içinde çekilecek telgrafların ücretlerini Matbuat Müdiriyet-i Umumiyesi (Basin Genel Müidürlüiği) bütçesine konulan ödenekten «mahsup ettirmeğe» 1926 yilını da kapsamak üzere yetkilidir (m. 1, 2)-

Ilk on yllık sürenin sonuna dogru çıkarılan 1 Aralık 1934 tarih ve 2594 sayılı Kanun ${ }^{12}$, Anadolu Ajansı ile ylllık ödenecek miktarı 150.000 lirayı geçmemek üzere on ylla kadar "taahhüt icrasına" yine Dıșişleri Bakanını yetkili saymıştır (m. 1).

22 Mayıs 1940 tarih ve 3837 sayılı Kanun'la ${ }^{13}$ Matbuat Umum Müidürłüği yeniden Başbakanlığa bağlı bir örgüt olarak kurulurken, Anadolu Ajansı T.A.Ş. ile aynı miktar ve süre için «taahhüt icrasında» bulunma yetkisi de bu Genel Müdürlüğe verilmiş (m. 5); daha önce 2594 sayılı Kanun'a göre Dișişleri Bakanlı̆̆ ile Anadolu Ajansı T.A.Ş. arasında yapılan sözleşmeden doğan hak ve yüküimler bu Genel Müidürlüğe devredilmiştir (muv. m.1).

b) II. D ï n a S a va \$̧ $1 \mathrm{nda} 4266 \mathrm{~S}$ a y $111 \mathrm{~K}$ anunla Gelen D üzenlem e

Ikki yıl sonra II. Dünya Savaşının ortasında «3837 say1lı Kanu* na ek» olarak çıarilan 17 Haziran 1942 tarih ve 4266 sayılı Kanun ${ }^{14}$, Anadolu Ajansı-Devlet ilișkileri bakımından önemli yeni hü. kümler getirmiştir. Yeni Kanun'a göre Matbuat Umum Müdürlüiğü, Anadolu Ajansı'nm yayın ve istihbarat işlerini, büiçe ve kadrosu ile uygulamasını denetlemeğe ve ödenecek miktarı her yl kendi bütçesinin Anadolu Ajansı bölümüne konulan ödeneği geçmemek üzere, en çok beş yıllık sözleşme yapmağa yetkilidir; bu sözleșmede Ajans Genel Müdürü ile Yönetim Kurulu üyelerinin atanma tarzlart da saptanir (m. 1).

Görülüyor ki yeni düzenleme, Anadolu Ajansı'nın anonim ortaklık statüisü çerçevesindeki hukukî ve malî özerkliğini geniş ölçüude zedeleyebilecek öğeler taşımakta, dolayısıyla bir bakıma Ajans'ın

"Anadolu Ajansı Şirketi Tarafindan Çekilecek Dahilî Telgrafnamelerin Ǔcretleri Hakkunda Kanun.

12 Anadolu Ajansı ile 10 Seneye Kadar Taahhüdat Icrası Için Hariciye Vekilliğine Salâhiyet Verilmesi Hakkında Kanun.

${ }^{13}$ Başvekâlete Bağlı Matbuat Umum Müdürlǚüü Teşkiline ve Vazifelerine Dair Kanun.

${ }^{14}$ Başvekâtete Bağlı Matbuat Umum Müdürlüğü Teşkiline ve Vazifelerine Dair 3837 Saylı Kanuna Ek Kanun. 
"yarı resmî" niteliğini vurgulamaktadır. Kanun Tasarısına iliş. kin tek cümlelik Hïkümet Gerekçesinde sadece "Şimdiye kadar yapılan tecrübelere nazaran, Anadolu Ajansı'nın istikbaldeki faaliyeti hakkında bazı hükümler vazedilmesi lüzumu hâsıl» olduğu yazılıdır ${ }^{i 3}$. Buna karşllık, Tasanya Türkiye Büyük Millet Meclisi'nce kabul edildiği biçimi veren Bütçe Komisyonu'nun Tutanağında daha ayrıntılı bir açıklama yer almıștır :

«Devletin siyaset ve emniyetiyle alâkalı havadisleri toplamak ve neșretmek gibi mührim bir amme hizmeti ifa eden Anadolu Ajansı'nm bu hizmetlerin ifası bakımmdan Matbuat Umum Müidürlüğü'nüm murakabesine tabi tutulması kadar tabî̂ ve lïzumlu bir șey olamaz. Bundan başka mezkûr Ajans'a yapılan büyüik nispetteki yardım dolayısıyla bütçesi ve kadrosu üzerinde ve hassaten Ajans'ịn faaliyetini tanzim ve tedvir edecek olan Umum Mïdüriyet'in t.dare Meclisi azasımm tayin şekli hakkknda da söz sahibi olması gerekli görülmüsştür»" ${ }^{16}$.

4266 sayıl Kanun'un dikkati çeken bir yan da, geçici bir hükümle yeni düzenlemeye hemen ișlerlik kazandıracak bir malî yaptırıma yer vermesidir: Matbuat Umum Müdürlügüi. 1942 malî yılı bütçesinin Anadolu Ajansı bölümüne eklenen 150.000 líranın ödenmesi, yeni dïzenlemeye göre sözleșme yapılması koșuluna bağlıydı (muv. m.). Bu geçici hïküm, Anadolu Ajansı T.A.Ş. ile Matbuat Umum Müdürlügü arasmdaki sözleşmenin «bir an evvel yapılması. $\mathrm{n} 1$ temin için» Bütçe Komisyonu'nca konmuștu ${ }^{17}$.

c) Son raki G e $1 \mathrm{i}$ s mele r ve Turizm ve T a n it m a B a k a n lı ğ K a n u n u'n un 33. $M$ a d d es i

4266 saylı Kanun'la getirilen düzenleme, 一olduğu gibi- ertesi yll çıarılan 16 Temmuz 1943 tarih ve 4475 sayılı Kanum'a ${ }^{18}$ geçirilmiş; buna sadece - yeni adıyla- Basın ve Yayın Umum Müidïrlüğï'nün Anadolu Ajans'inda sürekli bir denetçi bulunduracağına ilişkin bir fıkra eklenmiştir (m. 36). Daha sonra 4475 sayıl Kanun'-

15 TBMM Zabıt Ceridesi, C. 26 (1942), S. Sayıs1 : 205 «Başvekâlete Bağıı Matbuat Umum Müdürlü̈̆ü Teşkilât ve Vazifelerine Dair Olan Kanuna Ek Kanun Lâyihası ve Bütçe Enciumeni Mazbaatası (1/830)», s. 1.

16 TBMM Zabit Ceridesi, C. 26 (1942), S. Sayısı : 205, s. 1.

$\checkmark$ TBMM Zabit Ceridesi, C. 26 (1942), S. Sayıs1 : 205, s. 2.

18 Basın ve Yayn Umum Müdürlǚüi Teşkilât, Vazife ve Mennurlan Hakkinda Kanun. 
daki düzenleme, öz Türkçe akımına uygun bir dille 24 Mayıs 1949 tarih ve 5392 sayılı Basın-Yayın ve Turizm Genel Müdürlüğü Kanu. nu'na alınmıs (m. 29); 5392 sayılı Kanun'daki düzenleme ise, Turizm ve Tanıtma Bakanlığı'na uyarlanmıs olarak küçük bazı deği. șikliklerle 2 Temmuz 1963 tarih ve 265 sayll Turizm ve Tanıtma Bakanlığı Kanunu'na aktarılmıștır. Böylece kınk yıla yakın bir dönemi kapsayan bir hukuk gelişmesi, Turizm ve Tanıtma Bakanlığı Kanunu'nun 33. maddesinde noktalanmıştır. "Anadolu Ajansı ile sözleşme» kenar bașhı̆ını taşıyan bu madde şöyledir:

«Bakanlık, Anadolı Ajansının bütçesini, kadrosunu ve bunların uygulanmasını denetlemeye ve ödenecek miktar, her yll kendi büitçesinin Anadolu Ajansı bölümündeki ödeneği aşmamak üzere, Anadolu Ajansı ile en çok beş yıllık sözleşme yapmaya yetkilidir.

Bu sözleşmede, Anadolu Ajansı yöneticilerinin atanma yolları da belirtilir.

Bakanlık, Anadolu Ajansında bir denetçi bulundurur».

d) An adolu Ajansı T.A.Ş. Yöneticilerinin A t a n a sinda Etkili Olmak

Görülldüğui gibi bu madde, Turizm ve Tamima Bakanlığı'na, dolayısıyla Hükümete sadece Anadolu Ajansı T.A.Ş.'ni denetleme yetkisi değil, aynı zamanda yöneticilerinin atanmasını etkileme olanağı vermektedir. Gerçekten Anadolu Ajansı T.A.Ş. ile yapılacak sözleşmede Yönetim Kurulu üyeleriyle Genel Müdürün atanması belirli koşullara bağlanabilir; örneğin Yönetim Kurulunda Maliye Bakanlığı ile azınlik pay sahiplerinin belirli oranlarda temsili, Genel Müdür için Turizm ve Tanrtma Bakanlı̆g'non veya Hükümetin onayı aranabilir. Nitekim Anadolu Ajansı - Devlet ilișkilerinin dü. zenlenmesinde en önemli hukutkî aşama olan 4266 sayılı Kanun'a ilişkin Hükümet Tasarısında Ajans Genel Müidürüinüun Başbakanın onayı ile atanması önerilmiş (m. 3); fakat Türkiye Büyük Mïllet Meclisi Bütçe Komisyonu, - daha esnek ve daha geniş kapsaml bir hüikümle- Anadolu Ajansı T.A.Ș. ile yapılacak sözleșmede Ajans Genel Müidürü ile Yönetim Kurulu tuyelerinin atanma tarzlarmin da saptanmasını kabul etmişti (m. $1 / \mathrm{II})^{19}$. Her ne kadar günümüzde Turizm ve Tanıtma Bakanlığ Kanunu'nun 33. maddesi, Anadolu Ajansı ile yapılacak sözleşmede Ajans «yöneticilerinin» atanma

9 TBMM Zabıt Ceridesi, C. 26 (1942), S. Sayısı: 205, s. 3. 
yollarının belirtileceğinden söz etmekte ise de (f. II); bu hïkmüin Ajans Genel Müdürü ile Yönetim Kurulu üyelerini kapsadığını yukarda anlatılan hukukî gelişme açıkca göstermektedir.

Fakat 33. maddenin Turizm ve Tanıtma Bakanlığı'na, dolayısıyla Hüküimete vendiöi Anadolu Ajansı T.A.Ş.'ni denetleme yetkisi ile yöneticilerinin atanmasın etkileme olanağından simdiye değin ancak çok sınırlı bir ölçüide yararlanıldı̆ı anlaşılmaktadır. Bunda Turizm ve Tanıtma Bakanlığı Kanunu döneminde işbaşına gelen siyasal kadnolarla Anadolu Ajansı T.A.S. yöneticilerinin genellikle aynı siyasal dogrultuda bulunmalarn rol oynamıs olabilir.

Aslında 33. madde, siyasal iktidarların tutumuna göre farklı uygulamalara elverişli bir dïzenlemedir. Bu düzenlemenin siyasal iktidara verdi ̧̧i olanak, Anadolu Ajansı T.A.S. yönetiminde Anayasamızın 121. maddesindeki tarafsızlık ilkesinin gerçekleşmesini sağlayıcı bir denge öğesi olarak değerlendirilebileceği gibi; tarafsızlık ilkesinden saptırıcı bir malî baskı veya kayırma aracı olarak da kullanılabilir. O yüzden Turizm ve Tanitma Bakanlığı Kanunu'nun II. Dünya Savaşı koşulları içinde biçimlenmiş bir düzenlemeyi sürdüren 33. maddesini Anadolu Ajansi'nda tarafsılttk ilkesinin işlerliği için yeterli bir güvence saymak güçtür.

\section{B - Anadolu Ajansı'nı Özerk/Tarafsız Bir Kamu Tüzelkişiliğ̀i Olarak Yeniden Orgitlemek}

Görüldüğui gibi, Anadolu Ajansı́nın durumunu anonim ortaklık statüsü içinde düzeltmeğe yönelik çöziim yolları olarak incelediğimiz seçeneklerde Ajans'un siyasal iktidarlarm etkisi, hatta kontrolü altına girmesi olasılığ belirgin bir yer tutmaktadır. Us. telik bunlardan bazılarmın uygulanmasında ggüçlüklerle karşılaşılabileceği anlaşılmaktadır.

O yüzden Anadolu Ajansı sorunu için anonim ontaklık statüsii dışında da bir çöztim yolu aramak yararlı olacaktır. Böyle bir çözüm yolu, Anadolu Ajansı'nın özerk/tarafsız bir kamu tüzel kişiliği olarak yeniden öngütlenmesinde bulunabilir. Başlangıçta da değindiğimiz gibi, Kurtuluş Savaşı sonrasında Anadolu Ajansinın anonim ontaklık durumuna getirilmesindeki amaç, zaten Ajans'a normal zamanların koşulları içinde yaptığı işlerin özelliklerine uygun bir hareket serbestliği, başka bir deyişle belirli bir özerklik kazandınmaktı. Henüz özerk/tarafsız kamu tüzelkişiliği kavramı. nın gelişmediği 1924 Anayasası döneminde konunun özel hukuk hüküumlerine tabi bir kuruluş yapısı içinde ele alınması doğaldı. 
Ancak bir yandan Anadolu Ajansı T.A.Ș. Anasözleşmesinin Genel Kurulda oy hakkının kısrtlanmasına ilişkin hükümlerinin zamanla azınlık yönetimine yol açan çarpuk bir sisteme dönüişmesi, öbür yandan II. Dünya Savaşı koşulları içinde 4266 sayllı Ka* nun'la biçimlenen ve günümüzde 265 sayll Turizm ve Tanıtma Bakanlığı Kanunu'nun 33. maddesiyle sündürülen düzenkemenin Anadolu Ajansı T.A.Ş.'nin hukukî ve malî özerkliğini geniş ölçiide zedeleyebilecek nitelik.te olması karşısında, Ajans için 1925 'te bulưnan anonim ortaklık formülünün hâlâ geçerliğini koruduğu kolaylıkla söylenemez. Buna karşılık Anadolu Ajansı'nın vaktiyle anonim ortaklık durumuna getirilmesiyle güdülen amacu şimdi 1961/1971 Anayasasının 121. maddesi anlamında bir özerk/taraf. s1z kamu tüzelkişiliği içinde daha iyi gerçekleştirilmesi olanağı vardır.

Anadolu Ajansı'nın özerk/tarafsız kamu tüzelkişilił̆i olarak yeniden örgütlenmesi, iki aşamada tamamlanabilir:

\section{Anadolu Ajarst T.A.Ş.'nin Devletleștirilmesi}

Ilk aşamada yapılacak iş, Anadolu Ajansı T.A.Ş.'nin özel teşebbüs niteliğinin kaldırılması, başka bir deyişle devletleştirilmesidir. Bilindiği gibi Anayasamız, kamu hizmeti niteliği taşıyan özel teşebbiislerin kamu yararının gerektirdiği durumlanda gerçek kar. șlıkları kanunda gösterilen biçimde ödenmek koşuluyla devletleş. tirilmesine olanak tanımaktadır (m. 39 c. 1).

Imdi başlangıçta zaten bir Devlet dairesi olan Anadolu Ajansı́nın bir kamu hizmeti gördïğ̈ine şüphe yoktur. Anadolu Ajansı T.A.Ş. üzerindeki Devlet denetimini ilk kez düzenleyen ve şimdiki Turizm ve Tanıtma Bakanlı̆̆ı Kanunu'nun 33. maddesinin öncüsü olan 4266 saylı Kanun Tasarısma ilişkin Bütçe Komisyonu Tutanağında yazılı gerekçeler arasında —daha önce gördügüumïz gibiAjans'ın "mühim bir amme hizmeti ifa" ettiği de belirtilmiștir" 27 Mayıs 1960 Devriminden sonra çıarılan 12 Ağustos 1960 tarih ve 57 sayl Anadolu Ajansinın Malları ve Personeli Hakkında Kanun'un da Ajans'in bir kamu hizmeti gördüüü düșüncesine dayandığı açıktır. Gerçekten bu Kanun'a göre, ceza hukuku açısından Anadolu Ajansi'nun mallar Devlet malı, personeli Devlet memuru'sayılır (m. 1-2, geç. m.; krş. Türkiye Radyo-Televizyon Kurumu Kanunu m. 22, 40).

Öte yandan özel teşebbüsçe yürütülen bir kamu hizınetinin

20 TBMM Zabit Ceridesi, C. 26 (1942), S. Sayısı : 205, s. 1 (yulk. III A 4 b), 
doğrudan dogruya Devlet veya bir kamu tüzelkişisince yaplmasinun toplumsal gereksinmelere daha uygun dusștïğii her durumda kamu yararının varlı̆̆ı kabul edilebilir. Hele Devletin malî yardımiyla desteklenen, daha doğrusu ancak bu yardımla yürütülebilen bir kamu hizmetinin doğrudan doğruya Devlet veya bir kamu tüzelkişisince üstlenilmesinde kamu yararı daha belirgin olabilir. Iște Anadolu Ajansı T.A.Ş.'nin de Devletten aldı̆̆ malî yardımın Anayasal koşulu ve yaptığı hizmetin gereği olan tarafsızlık ilkesinin işlerliğini güvence altına alacak bir hukukî statüye kavuşturulmak üzere devletleştirilmesinde kamu yararı bulunduğu kolaylıkla söylenebilir.

Fakat genel olarak bir teşebbüsüin kamu hizmeti niteliği taş1. dığını veya bu niteliği kazandığını ve devletleştirilmesinde kamu yararı bulunduğunu, yaşanan çă̆ın anlayışına ve toplumsal gereksinmelere göre ancak kanun koyucu takdir edebileceğ gibi ${ }^{21}$; Anadolu Ajansi T.A.S. için de bu koşulların gerçekleştiğini kanun koyucu saptayacaktır. Çünkï devletleștirme bir kanun konusudur.

Anadolu Ajansı T.A.Ş. gibi pay senetlerinin yarıya yakın bir bölümü zaten Hazine'ye ait bir anonim ortaklığın devletleştirilmesinde izlenebilecek. en basit yol, bu amaçha çıkarılacak kanunda geri kalan pay senetlerinin "gerçek" değerleri üzerinden Devlete devredildigininin öngörülmesidir ${ }^{22}$. Böylece Devlet Anadolu Ajansı T.A.Ş.'nin tek pay sahibi durumuna gelmis, dolayısıyla Anadolu Ajansı T.A.Ş.'nin bütün malvarlı̆̆ı Devlete geçmiş olacaktır. Hemen söyleyelim ki, bu aşamada Anadolu Ajansı T.A.Ș.'nin özel teşebbiis niteliği kaldırılmıs olmakla birlikte, anonim ortaklık olarak hukukî varlı̆̆ı henuiz sona ermiş değildir. Ikinci aşamaya kadar Anadolu Ajansı T.A.S.'nin tek pay sahipli anonim ortaklık

${ }^{21}$ Aynı yönde bk. Ali Utkï Azrak, Millileștirme ve Idare Hukuku, Istanbul 1976, s. 38 vdd, 54, 228 vd; Akm Düren, Devletin Mülkiyete El Atmasindan Dợan Tazmin Yükümlïlï̈̆̈ü, Ankara 1977, s. 91-93.

22 Geçmişteki Türk uygulamasundan bu yönde bir örnek olarak bk. 5 Temmuz 1939 tarih ve 3688 sayll Ankara Elektrik, Ankara Havagazı ve Ankara Elektrik Türk Anonim Şirketleri Hisse Senetleriyle Hak ve Vecibelerinin Satın Alınmasına Dair Mukavelelerin Tasdikına ve Bu Şirketlerin Muvakkat Işletmeleriyle Satın Alma Bedellerinin Tesviye Tarzına Dair Kanun m. 1, 3.

Fransiz tygulamasından örnekler olarak bk. Loi du 2 décembre 1945. relative à la nationalisation de la Banque de France et des grandes banques et à l'organisation du crédit, art. 1; Loi du 25 avril 1946, relative a la nationalisation de certaines sociétés d'assurances et à l'industrie des assurances en France, art. 7. 
olarak hukukî varltğınt sürdürmesi, Türk Ticaret Kanunu'nun anonim ortaklıklarda pay sahipleri sayısının beșten aşağıya düș. mesine geçici olarak olanak tanıyan sistemine aykırılk yaratmaz. (m. 435, krş. 434/4).

Anadolu Ajansı T.A.Ş.'nin devletleştirilmesi amacıyla çıkarılacak kanunda Hazine'ye ait pay senetleri dışındaki pay senetleri karşıllı̆̆ının nasıl saptanacağı ve ödeneceği de gösterilmelidir. Anadolu Ajansı T.A.Ş. pay senetleri borsada kayıtlı olmadığına göre, bunlar için ödenecek karşılığın Anadolu Ajansı T.A.Ş. malvarlığının tasfiye değerine oranlanarak hesaplanması gerekecektir ${ }^{23}$. Fakat Anadolu Ajansı T.A.S.'nde Hazine'ye ait pay senetleri dışındaki pay senetlerinden çoğunun səhipleri veya mirasçılarının şimdi artık adresleri dahi bilinmediği, hatta büyüik bir olasıllkla bu pay senetleri kayıp olduğu için; Devlete devredilecek pay senetleri karşılığında ödenecek para gerçekte önemli bir yekûn tutmayacaktır. O yüzden Anayasamızın devletleștirmede olanak tanıdığı taksitle ödeme yoluna gidilmesine de gerek yoktur (m. 39 c. 2$)$.

2. Anadolu Ajanst'ntn Özerk/Taratstz Kamu Tüzelkişiliği Olarak Yeniden Kurulmast

İkinci aşamada yapılacak iş, Anadolu Ajansi'nun anonim ortak. lık olarak hukukî varlığına son verilmesi ve aynı anda 1961/1971 Anayasasmın 121. maddesi anlamında özerk/tarafsız kamu tiuzelkjşiliği olarak yeniden kurulmasıdır ${ }^{24}$. Böylece Anadolu Ajansı T.A.Ş.' nin sona ermesi ile yeni kamu tüzelkişiliğinin kurulması arasında herhangi bir kesintiye meydan vermeksizin Ajans'n sürekliliği sa ğlanmıș olacaktır. Bilindiği gibi Anayasamız, kamu tüzelkişiliğinin ancak kanunla veya kanunun açıkça verdiği yetkiye davanılarak

${ }^{23}$ Fransız uygulamasından bu yönde örnekler olarak bk. Loi du 2 décembre 1945. relative à la nationalisation de la Banque de France et des grandes banques et à l'organisation du crédit, art. 2; Loi du 25 avril 1946, rèlátive à la nationalisation de certaines sociétés d'assurances et à l'industrit' des assurances en France, art. 10.

24 Bilindiği gibi, 1961 Anayasasını 121. maddesiyle radyo ve televizyon istasyonlarn için getirilen "özerk kamu tüzelkişiliği» kavramı, 20 Eylü] 1971 tarih ve 1488 sayıll Kanun'la yaptlan deģișiklikten sonra yerini "tarafsız bir kamu tüzelkişiliž̀i" kavramtna bırakmıştır (f. I). Fakat ayn: maddede "Devlet tarafindan kurulan» haber ajanslarının hukukî yapıs' hakkında herhangi bir açılık olmadığı için (f. IV), yeni Anadolu Ajansı'nın bu iki kavramdan birine veya öbürüine göre örgütlenmesí, tamamıyla kanun koyucunum takdirine kalmış bir konudur. Kesin olan şey, her iki durumda da tarafsızlik ilkesinin geçerliğini koruyacağıdır (f. IV, krş. II). 
kurulacağını öngörmektedir (m. 112/III). Anadolu Ajansı'nm özerk/tarafsız kamu tüzelkişiliği olarak yeniden örgüitlenmesi amacıyla çıkarılacak kanunda bir yandan yeni kamu tüzelkişisinin kurulduğu açıklanırken, öbür yandan Anadolu Ajansı T.A.Ş. malvarlığının bütün aktif ve pasifleriyle yeni kamu tüzelkişisine geçtiği belirtilmelidir. Böylece yeni kamu tüzelkișisi Anadolu Ajansı T.A.S. nin küllî halefi olarak çalışmaya başlayacağı gibi, sona eren Anadolu Ajansı T.A.S.'nin ayrıca tasfiye edilmesine gerek kalmayacaktır (krş. Türk Ticaret Kanunu m. 439/I, 454).

Çıkarılacak kanunda özellikle dikkate alınması zorunlu bazı Anayasa ilkeleri de vardır: Bunların başında radyo ve televizyon istasyonlar kadar belirli nitelikteki haber ajansları için de öngörüilmüs bulunan tarafsılık ilkesi gelir. Anadolu Ajansı'nın "Devletten malî yardım alan" bir haber ajansı durumundan dogrudan doğruya "Devlet tarafindan kurulan» bir haber ajansı durumuna getirilmesi, bu ilkenin geçerliğinde bir değişiklik yapmayacaktır (m. 121/ IV). O yüzden Anadolu Ajansı için çıkarılacak kanunda özellikle yeni kamu tüzelkişisinin görevleri, habercilik ve yayın politikası, yönetim ve denetimi tarafsızlık ilkesinin işlerliğini güvence altına àlacak biçimde düzenlenmelidir. Örneğin yönetim kurulunda Hüküimet temsilcisi yanında Ajans: çalışanları ile TRT, basın ve hatta üniversite temsilcilerine yer verilmesi, tarafsızlık ilkesine uygun bir denge tedbiri olarak düşünülebilir. Şüphesiz Anadolu Ajansı'nun yeniden örgütlenmesinde ilk özerk/tarafsız kamu tüzelkişiliği ola. rak TRT modelinden --edinilen tecrübeleri de degerlendirmek kaydıyla- yararlanılabilir. Fakat Anadolu Ajansı için herhalde kendi ölçeğine göre TRT'ye oranla·çok daha basit bir örgüt şeması yeterli olur.

Yine Anayasa uyarınca «kamu tüzelkişileri elindeki basın dıșı haberleşme ve yayın araçlarından" kișiler ve siyasal partilerin yararlanma hakkının koșulları ve usulleri, «demokratik esaslara ve hakkaniyet ölçülerine uygun olarak», fakat "Devletin üllkesi ve mil. letiyle bütünlügüunün, insan haklarına đayanan millî, demokratik, layik ve sosyal Cumhuriyetin, millî güvenliğin ve genel ahlâkın ko. runması halleri dıșında kalan bir sebebe dayanarak halkın bu araçIarla haber almasını, düșiunce ve kanaatlara ulaşmasını ve kamuo yunun serbestçe oluşumunu engelleyici kayıtlar» koymaksızın kanunla düzenleneceği için (m. 26, krş. 121/III); Anadolu Ajansı'mn özerk/tarafsız kamu tüzelkișiliği olarak yeniden örgütlenmesi amacıyla çıarılacak kanunda bu konuya ilişkin hükümlere de yer ve. 
rilmesi gerekecektir (krş. Türkiye Radyo-Televizyon Kurumu Kanunu m. 2, 11-19).

Ekleyelim ki, yukarda ana çizgileriyle anlatmaya çalıștığımız "Anadolu Ajansı T.A.Ş.'nin devletleștirilmesi» ve "Anadolu Ajansi'nın özerk/tarafszz kamu tüzelkişiliği olarak yeniden kurulması" aşamaları, iki ayrı kanun konusu olarak ele alınabileceği gibi; tek bir kanunla da düzenlenebilir.

\section{BIR KARŞILAŞTIRMA VE SONUÇ}

Görüldügüi gibi, Anadolu Ajansı'nın durumunu anonim ortaklık statüsü içinde düzeltmeğe yönelik çözüm yolları arasında « $7 \mathrm{sa}$ yllı Kanun'u kaldırmak veya değiş̧irmek» başhı̆ı altında inceledi. ğimiz ikinci seçenek ile bu son çözüm yolunun ortak bir yanı var. drr: Her ikisi de sorunun yasama organı diuzeyinde ele alınmasını gerektirmektedir. Fakat söz konusu seçenekte yasama organının işe karışması, sadece Anadolu Ajansı T.A.Ș.'nin Kanunname-i Ticaret döneminden kalma Anasözleşmesini Türk Ticaret Kanunu'nun emredici hükümlerine uydurmasın zorunlu kulmak, —bașka bir deyişle- şimdiye değin Anadolu Ajansı T.A.Ş. Anasözleşmesinin Türk Ticaret Kanunu'nun emredici hükümlerine uydurulmasını önlemiş bir engeli ortadan kaldırmak amacıyla smurlı kalacak; ası! çözüm, bundan sonra Anadolu Ajansı T.A.S. Anasözleșmesinin değiştirilmesiyle gerçekleştirilecektir. Ancak böyle bir değişiklikte tarafsizlık ilkesine uygun denge tedbirlerine de yer verilmesi kesin olmadığ 1 gibi, anonim ortaklık yapısi içinde alınacak herhangi bir tedbirin yine aynı yapı içinde her zaman kaldırlabileceği veya değiştirilebileceği açıktır.

Anadolu Ajansı'nın durumunu anonim ortaklık statüsü dıșında düzeltmeğe yönelik son çözüm yolunda ise Ajans'in özerk/tarafsız bir kamu tïzelkișiliği olarak yeniden örgütlenmesi yasama organınca gerçekleştirileceği için; getirilecek düzenleme, daha kalıcı ve daha güvenceli olabilir. Konuya bu açıdan da bakıldığında son çözüm yolunun üstünlügü ortadadır.

Incelememizi bitirirken șu noktaya da işaret etmek isteriz ki, Anacoolu Ajansı'nı uzun süre kısır siyasal çekişmelerin ortasında tutmakta yarar yoktur. Anadolu Ajansi'nı bir an önce tarafsızlı̆̆ tartısma konusu olmayan bir ulusal haber ajansı durumuna getirmek, hukukî yapıs:'n buna göre yeniden düzenlemek zorunludur. 


\section{BIBEIYOGRAFYA}

Anadolu Ajansı Türk Anonim Şirketi Nizamname-i Dahilisi, Istanbul 1925-1341.

Anadolu Ajansı Türk Anonim Şirketi, Sermayesi 20.000 Türk Lirası, Merkez-i Idaresi : Ankara, Mümessillikleri : Istanbul, Izmir, Adana, Haricî Muhabirlikleri : Cenevre, Bïkres - Meclis-i Idare Raporu ve Murakıp Raporu, 1925 ve 1926 Seneleri Bilançoları ve Kâr ve Zarăr Hesabı, Ankara 1927.

Halil ARSLANLI, Anonim Şirketler, II-III, Istanbul 1960.

Ali Ulkü AZRAK, Millileștirme ve tdare Hukuku, Istanbul 1976.

Akm DUREN, Devletin Mülkiyete El Atmasından Doğan Tazmin Yükü̈rnlülüğ̈i, Ankara 1977.

Halid Kemat ELBIR, Gerekçeli-Not\}uSistematik Türk Ticaret Kanunu ve Tatbikat Kanunu ile Alâkalı Mevzuat, 2. bast, Istanbul 1958.

Fritz FUNK, Kommentar des Obligationenrechtes, Bd. II, Aarau 1951.

Yaşar KARAYALÇIN, Özel Hukukda Meseleler ve Görüșler «Hukukî Mütalâlar», Ankara 1975.

E. SCHUCANY, Kommentar zum Sohweizerischen Aktienrecht, 2. Aufl., Zürich 1960 .

Astan Tufan YAZMAN, «Anadolu Ajansı», tktisat ve Ticaret Ansiklopedisi, C. I, Istanbul 1946. 


\section{KISALTMALAR}

Al.

Art., art.

Aufl.

Bd.

bk.

C.

c.

dn.

f.

Fr.

geç, $\mathrm{m}$.

krs.

m.

muv, $m$

N.

S

s.

56

T.A.Ș.

vd

vda

yuk.
: Almanca

: Artikel, article

: Auflage

: Band

: bakiruz.

: Cilt

: cümle

: dipnotu

: f1kra

: Fransızca

: geçici madde

: karşilaștirınız

madde

: muvakkat maddc

: Nummer

: Say

: savfa

: son cümle

: :Türk Anonịm Şirketi

: ve devamı sayfa

: ve devami sayfalar

: ýukarda. 